\title{
Urgences
}

\section{Je marche dans...}

\section{Claire Bienvenue}

Numéro 15, octobre 1986

Épigraphiques

URI : https://id.erudit.org/iderudit/025357ar

DOI : https://doi.org/10.7202/025357ar

Aller au sommaire du numéro

Éditeur(s)

Urgences

ISSN

0226-9554 (imprimé)

1927-3924 (numérique)

Découvrir la revue

Citer ce document

Bienvenue, C. (1986). Je marche dans... Urgences, (15), 101-101.

https://doi.org/10.7202/025357ar

Ce document est protégé par la loi sur le droit d'auteur. L'utilisation des services d'Érudit (y compris la reproduction) est assujettie à sa politique d'utilisation que vous pouvez consulter en ligne.

https://apropos.erudit.org/fr/usagers/politique-dutilisation/
Cet article est diffusé et préservé par Érudit.

Érudit est un consortium interuniversitaire sans but lucratif composé de l’Université de Montréal, l'Université Laval et l'Université du Québec à Montréal. Il a pour mission la promotion et la valorisation de la recherche. https://www.erudit.org/fr/ 


\section{Claire Bienvenue}

rien ne devrait recevoir un nom de peur que ce nom même le transforme

Virginia Woolf: Les vagues

Je marche dans un rêve Aux pieds lourds chaussés de racines

À froisser les nappes de brume Je tourne autour de la table carrée

Toujours je recommence

Je ne sais pas que je rêve Ou j'oublie Il suffirait les yeux clos

Peut-être D'inverser le temps comme on retourne un gilet $\quad \grave{A}$ l'envers

Je me rapproche De quoi au juste?

J'aurais voulu ne pas les entendre ne pas les apercevoir ces petits monstres verts qui sortent des bouches dare-dare se bousculent $\mathrm{m}$ ' $\mathrm{i}$ noculent...

À marée basse Des yeux Des yeux qui me lient Descentaines de pupilles pétrifiées immobilisées Pierres à crapauds Une pierrée dans le sable Où je m'écoule Femme liquide.

Je dois retourner chez lui Chez moi? Vivre la parenthèse Je respire par la feuille comme certains végétaux Souffle sibilant entrecoupé La phrase

Je le voudrais là Immuable Intouchable $A$ le regarder sans pensées

Les aiguilles du temps au fond des tiroirs Ne pas savoir ne pas pouvoir LE NOMMER 